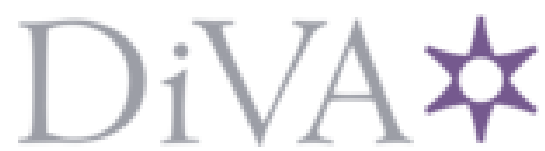

http://www.diva-portal.org

\title{
Postprint
}

This is the accepted version of a chapter published in Theoretical perspectives on family businesses.

Citation for the original published chapter:

Criaco, G. (2015)

Organisational ecology and the family business.

In: Mattias Nordqvist, Leif Melin, Matthias Waldkirch and Gershon Kumeto (ed.), Theoretical perspectives on family businesses (pp. 18-34). Cheltenham: Edward Elgar Publishing https://doi.org/10.4337/9781783479665.00009

N.B. When citing this work, cite the original published chapter.

Permanent link to this version:

http://urn.kb.se/resolve?urn=urn:nbn:se:hj:diva-28769 


\section{Organisational Ecology and the Family Business}

\section{Giuseppe Criaco}

\section{Introduction}

Although the survival of family businesses is a central theme for both research and policy, no conceptual or empirical study in family business research exists that engages with organisational ecology theory. This gap is surprising given the relevance of this theory to the survival of distinct forms of organisations. One potential explanation for this lack of application may be that prior studies have theorised about family firms' survival on the individual- or firm-level (Sharma, 2004; Wilson, Wright \& Scholes, 2013), whereas organisational ecology primarily focuses on environmental-level determinants. This focus on the individual- or firm-level is surprising given Wortman's (1994) early encouragement that "studies examining [...] external environmental factors and their relationships to the family-owned business are needed” (p. 21). I use organisational ecology to explore the survival of family businesses and explain why and how organisational ecology can be implemented by family business research to explore the effect of certain dimensions of the environment on the survival of family businesses. As applied to the family business context, this theory maintains that certain environmental characteristics will affect the survival of family businesses as a particular type of organisational form or that the environment will select family businesses with particular characteristics.

This chapter offers three primary contributions. First, it contributes to research in family business by adopting organisational ecology to understand the impact of environments on the survival of family businesses. Although “[T]heories such as (...) population 
ecology might be used in such endeavours” (Sharma, 2004, p. 22), the application of the ecological perspective to the family business context is still rare. Second, this chapter contributes to research in both entrepreneurship and family business by theorising that systematic differences in the survival of family businesses primarily suggested by micro-oriented studies may also manifest themselves at the environmental level (see also Bird \& Wennberg, 2014). While some studies observe that family businesses are over-represented in certain industries (see Westhead \& Cowling, 1998; Villalonga \& Amit, 2006; Gedajlovic \& Carney, 2010), such as luxury-related industries (Carcano, Corbetta \& Minichilli, 2011), construction (Gomez-Mejia, Larraza-Kintana \& Makri, 2003), and discount shop retailers (The Economist, 2009), and under-represented in others (see Villalonga \& Amit, 2006), there are important theoretical gaps assessing the dynamics that regulate this phenomenon (i.e., the creation of new firms and failure of existing firms in such industries). Finally, this study contributes to research in organisational ecology by applying some core concepts of this perspective in a novel empirical context, i.e., the family business.

The paper is structured in the following way: section 2 provides a short overview of the organisational ecology perspective, and section 3 provides an analysis of how this perspective has been used in previous family business research. In section 4, I suggest how organisational ecology can inform family business research to elucidate the mortality of family businesses by focusing on environmental characteristics. Finally, the paper concludes by providing some implications for the theory in organisational ecology and family business research. 


\section{Organisational ecology: an introduction}

Organisational ecology investigates how social and environmental conditions influence (a) the rates of founding of new organisational forms, (b) the rates of mortality of organisational forms, and (c) the rates of change in organisational forms (Singh \& Lumsden, 1990; see also Amburgey \& Rao, 1996; and Baum, 1996). Organisational ecology arises as a critique to the adaptation perspective (e.g., structural functionalism) (Hannan \& Freeman, 1977; Astley \& Van de Ven, 1983), according to which organisations scan the environment for opportunities and threats and formulate strategic responses to adjust to them. Organisational ecologists reacted to this adaptation perspective, arguing that it exaggerates the degree to which managers of organisations can flexibly adjust their structural forms (Aldrich \& Pfeffer, 1976). The primary argument used to criticise this view relies on organisational inertia. Hannan and Freeman (1977) indeed suggest that internal (i.e., sunk costs, lack of complete information flow, internal political resistance to change, and historical precedents) and external pressure (i.e., legal barriers to entry and exit, acquisition of information about the environment, legitimacy constraints and collective rationality problems) are responsible for inducing a "structural inertia”, which in turn is considered to be a hindrance to organisational adaptation to the environment ${ }^{1}$.

In the following section, I highlight the main theoretical approaches and arguments undertaken by organisational ecologists to assess the influence of the environment on organisational mortality. The focus on this dimension is linked to the primary objective of this research, which aims at understanding how environmental factors may impact the

\footnotetext{
${ }^{1}$ However, organisational ecologists do not claim that organisations do not change. Instead, they suggest that organisations tend to "respond relatively slowly to the occurrence of threats and opportunities in their environments" (Hannan \& Freeman 1984, p. 151).
} 
mortality of family businesses. Finally, this section concludes with a brief discussion on the level of analysis in organisational ecology research.

\subsection{Organisational mortality}

In a review on theory and research in organisational ecology, Singh and Lumsden (1990) claim six approaches exist to studying organisational mortality: fitness set theory, resource partitioning, liability of newness, density dependence, liability of smallness, and the effects of founding conditions. Both fitness set theory and resource partitioning theory help to understand form-environment relationships. Population ecologists build upon Levins' (1962) fitness set theory to focus on two different aspects of environmental variation, i.e., variability and grain, to explain the relative prevalence and survival of two different typologies of organisations: specialists and generalists. While variability refers to the variance in environmental fluctuations about their mean over time, grain refers to the patchiness of these variations: many small periodic variations is fine-grained while few large periodic variations is coarse-grained. The definition of specialist and generalist organisations derives from Hannan and Freeman's (1977) niche-width theory. According to Freeman \& Hannan (1983), populations differ in niche width. Niche width “refers to a population's tolerance for changing levels of resources” (p. 1118). As a consequence, populations that have wide tolerance, i.e., they can reproduce in diverse circumstances, are known as generalists. Specialists are instead those organisational forms that have narrower levels of tolerance (Freeman \& Hannan, 1983). Such organisations usually possess few slack resources and focus on ways to exploit a narrow range of potential customers (Baum, 1996). On the one hand, fine-grained environments favour specialists' survival regardless of the level of environmental variability (Freeman 
\& Hannan, 1983) because specialists ride out environmental fluctuations (Singh \& Lumsden, 1990), while "generalists are unable to respond quickly enough to attain any degree of production efficiency” (Baum, 1996 p. 84). On the other hand, coarse-grained environments favour specialists' survival only for low levels of environmental variability, while generalists would be favoured for high levels (Freeman \& Hannan, 1983).

Carroll's (1985) resource partitioning is an alternative model of niche-width dynamics explaining the differential survival capabilities of specialists and generalists in environments characterised by economies of scale depending on the different degree of market concentration. Economies of scale in production and marketing imply that the best location for a generalist firm is in the centre of a concentrated market. As the level of concentration in a market increases due to the generalists' tendency to exploit the resources available at the market centre, the mortality rate of generalist firms also increases as they compete against each other to gain control over the market centre. A few larger generalist firms survive to dominate the market. The total resource space covered by generalist firms is smaller than it would be in a competitive, unconcentrated market where firms offer differentiated products or services. Therefore, in a concentrated market, specialist firms have access to more resources that are located on the periphery of the resource space. They can thus exploit peripheral market segments without directly competing with the larger generalists. As a result, as a market concentrates, the mortality rate of specialists should decrease and the mortality rate of generalists should increase. This approach is called resource partitioning because specialists and generalists appear to operate in difference resource spaces (Singh \& Lumsden, 1990).

The concept of liability of newness was first introduced by Stinchcombe (1965) to indicate new firms' propensity to fail compared to older ones for both internal and external 
reasons. Young organisations often involve new roles, which must be learned, while in older organisations, the former occupants of roles can teach their successors. The costs and time linked to learning in new organisations is high, and these organisations are less efficient than older ones until this learning occurs (Stinchcombe, 1965). Moreover, when managing external actors (e.g., customers, clients), new organisations are forced to compete with existing organisations that have well-established client groups who are familiar with the organisation. The failure of new organisations to attract actors from older organisations enhances their mortality. Hannan and Freeman (1984) provided further ecological arguments to support the liability of newness concept. These authors suggested that selection pressures favour organisations that are able to prove their reliability and accountability. Both dimensions require the organisational structure to be highly reproducible. The reproducibility of an organisation's structure, and consequently its inertia, increases with its age due to processes of internal learning, coordination and socialisation with external actors (Hannan \& Freeman, 1984). Again, because selection processes favour both reproducible and inert organisations, the mortality rate of organisations should decrease as they age.

Closely related to the liability of newness concept is the liability of smallness (Hannan \& Freeman, 1984). These authors claim that an organisation's structural inertia increases with its age, and because selection processes favour structurally inert organisations due to their reliability, larger organisations have lower mortality rates. Moreover, the propensity of small organisations to fail is also associated with problems, such as capital raising, recruitment and training of the workforce and the greater influence of governmental regulations (Aldrich \& Auster, 1986). As many new organisations are also 
small, the liabilities of newness and smallness have often been combined both theoretically and empirically (Baum, 1996).

In addition to the liability of newness concept, Stinchcombe's (1965) paper heavily influenced ecological research on the relationship between social and organisational structure at founding and subsequent survival (Wholey \& Brittain, 1986). According to Stinchcombe, some features of the social environment at the time of founding influence (or imprint) organisational processes. Indeed, “organisations formed at one time typically have a different social structure from those formed at another time” (Stinchcombe, 1965 p. 154). Carroll and Hannan (1989) proposed a general model that related density (the number of organisations in a population) at the time of founding to organisational survival. These authors believe that density leads to two problems that new entrants must address. First, resources are often scarce in high-density periods (liability of scarceness), conditions that spawn smaller and more fragile organisations. Second, high density may imply a tightly crowded niche, or market, where new entrants are pushed to the boundaries of the established resource space because they cannot compete directly with established organisations. They argued that both resource scarcity and tight niche packing affect the initial mortality rate of organisations. While some researchers have typically assumed that the effect of the environment at founding on organisational mortality is either permanent and unchanging (Romanelli, 1989) or an initial liability that declines proportionally (relative to other organisations' liability to fail) over an organisation's lifetime (Carroll \& Hannan, 1989), others instead claimed that the higher mortality rates experienced by organisations founded in adverse environmental conditions may not be permanent. Swaminathan (1996), for instance, extended this model, arguing that resource scarcity results in an initial liability only. However, tight niche packing results in a 
permanent liability for organisations founded under these conditions because "resource scarcity hampers the initial development of organisational capabilities, whereas tight niche packing affects the permanent competitive position of organisations within a population” (p. 1353). Moreover, the organisation's age is supposed to moderate the environment-survival relationship.

Finally, both the density dependence and the population dynamics arguments have been used to assess organisations' mortality. The primary argument here builds on Hannan's (1986) paper. This author argued that population density, or the number of organisations in a population, induces both legitimation and competitive forces. Growth in the number of organisations in a population legitimates the organisational form itself, thus decreasing the mortality rate. As density continues to increase, competitive pressures overcome the legitimation effects, thereby increasing mortality rates. One primary limitation of this argument is that each organisation in the population is considered to have an equivalent impact on mortality rates (Baum \& Mezias, 1992). To overcome this limitation, two additional concepts expanded the initial model: density delay and mass dependence (Baum, 1996). According to density delay, an organisations' mortality is not only a function of the population's contemporaneous density but also of the density at the time of founding. Specifically, it is proposed that organisations founded in high-density conditions experience higher failure rates due the liabilities of (resource) scarcity and tight niche packing (see above). However, mass dependence derives from the fact that larger organisations generate stronger competition than smaller rivals due to their superior access to resources, greater market power, and economies of scale and scope (Baum, 1996). Increases in population mass should thus have a competitive effect, increasing the failure of organisations (Barnett \& Amburgey, 1989). 


\subsection{Level of analysis}

In a review of organisational ecology empirical studies, Wholey and Brittain (1986) find that ecological research usually uses three classes of models to capture developmental processes at different levels of analysis. In the first class of models, the units of analysis are organisations and the dependent variables are some measure of the firm's performance, typically failure. An example of this type of model is Freeman and Hannan (1983), who studied differences in specialist and generalist restaurant failure rates as a function of different environments to test their hypotheses about specialism and generalism. They clearly stated that the "unit of analysis here is the individual establishment” (p. 1130). Other examples where the units of analysis are organisations and the dependent variables are performance measures, such as failure, have been found since the inception of empirical organisation ecology studies, for example, Carroll (1985), Carroll and Delacroix (1982), and Freeman, Carroll and Hannan (1983). The second class of models use environments, either industrial or geographical, as the units of analysis and the rates of firm arrival or exit as the dependent variables. An example of this type of model is given by Pennings (1982), who found that industrial differentiation, among others, is a strong predictor of organisational birth. Other commonly studied environmental determinants of organisational birth or mortality are resource availability/munificence, environmental uncertainty, frequency of environmental change, and magnitude of environmental change (Wholey \& Brittain, 1986). Finally, the third class of models uses multiple populations as the units of analysis in which competition coefficients are the parameters of interest. 


\section{Organisational ecology in family business research}

Although organisational ecology has been suggested as an alternative theoretical approach for understanding the impact of environments in the formation and endurance of family businesses (see Sharma, 2004), very few studies have made an effort to apply this theory to family business research. A systematic search in the Scopus ${ }^{2}$ and $\mathrm{ABI} / \mathrm{INFORM}^{3}$ datasets revealed only one relevant published article that applies organisational ecology theory to the empirical context of family business. In this paper, Bird and Wennberg (2014) construct a theoretical framework that explains how the regional context impacts family and non-family start-ups. The authors suggest that certain environments may be more or less conducive to specific types of start-ups and theorise that economic and social factors influence the birth of family and non-family start-ups in different ways. Specifically, they argue and find that rural regions characterised by lower income per capita, a large number of pre-existing small family businesses, and favourable community attitudes toward small businesses exhibit a higher prevalence of family startups. Conversely, regions characterised by higher levels of income per capita, a large number of pre-existing non-family businesses, and population growth exhibit a higher prevalence of non-family start-ups. As noted above, while this study is relevant as it opens up the potential application of organisational ecology in the field of family business (see Sharma, 2004), organisational ecology provides additional theoretical approaches and arguments that are worth applying in the empirical context of family business. First,

\footnotetext{
${ }^{2}$ The search code for Scopus is the following: TITLE-ABS-KEY (((population* OR organisation*) W/1 ecology) AND (family W/1 (business* OR firm* OR organisation* OR venture*))).

${ }^{3}$ The search code in ABI/INFORM is the following: AB (((population* OR organisation*) near/1 ecology) AND (family near/1 (business* OR firm* OR organisation* OR venture*))).
} 
different dimensions of the environment may be worth investigating. Although regions’ (or geographical) characteristics are important determinants of new firm creation, other environmental dimensions, such as industries, are believed to strongly influence the creation of new firms (Fritsch \& Falck, 2007). Second, environments are not only believed to affect the rate by which new firms are created, but they also influence the mortality rate of the organisational forms competing in these environments (Hannan \& Freeman, 1977).

Understanding the differences between family and non-family businesses is crucial for investigating which industry factors affect the survival of family businesses compared to non-family businesses, and vice-versa. The next section will briefly highlight the distinctiveness of family businesses.

\section{Towards an ecological perspective of family businesses}

\subsection{Family business as a distinct organisational form}

Research in family business has argued that the family business is exposed to the strong social system of the family (Aldrich \& Cliff, 2003; Wiklund, Nordqvist, Hellerstedt \& Bird, 2013), implying that structural family ties will spill over to the business (Arregle, Hitt, Sirmon \& Very, 2007). The direct effect of the family on the business has implications for the objectives, visions, and practices that family businesses pursue. Family businesses are believed to embrace a market-oriented logic through the founders, but at the same time, the social context of the family is believed to constrain the firm's economic objectives (Miller, Le Breton-Miller \& Lester, 2011) and lead to varying priorities and behaviours toward the business (Gómez-Mejía, Haynes, Núñez-Nickel, Jacobson \& Moyano-Fuentes, 2007). Family business research suggests that the 
distinctiveness of family businesses manifests itself in several particularities that may be relevant to their industry and to their mortality rates: family businesses constitute organisational forms with specific recruitment practices (Miller \& Le Breton-Miller, 2005), resource configurations (Habbershon \& Williams, 1999; Sirmon \& Hitt, 2003), and organisational cultures (Zahra, Hayton \& Salvato, 2004) that result in different visions and behaviour toward the industry (Carney, 2005). For instance, family businesses are believed to participate more frequently in industries that are less capital intensive (Gedajlovic \& Carney, 2010) and therefore have low-entry barriers (Ward, 1988) and labour-intensive production (Carney, 2005). The distinct preferences and behaviours of family businesses suggest that the industry factors important to their formation and survival are different than those for non-family businesses.

In the next sections, I propose a potential application of organisational ecology theory to the family business context using some theoretical arguments developed by organisational ecologists. The aim of these sections is thus to better understand the influence of the industrial environment on the survival of family versus non-family businesses from an organisational ecology perspective.

\subsection{Structural inertia in family businesses}

To see if the organisational ecology perspective is an appropriate theoretical lens for approaching the survival of the family business, I shall first discuss whether this type of businesses is exposed to structural inertia forces that prevent it from adapting to environmental conditions. Davis and Stern (1988) discussed the topic of the adaption of family-owned business. These authors proposed that "four interrelated components that are critical to the process of adaptation in the family business” (p. 74) exist: intersystem boundary conditions (family and business), emotional commitment, (lack of) 
development of task structures and processes, and (lack of) legitimisation structures. These authors then propose different strategies that family businesses should implement to overcome these issues. Consistent with this study, I propose that family businesses are exposed to selection forces due to intrinsic characteristics, such as a long-term orientation (Lumpkin, Brigham \& Moss, 2010), altruistic behaviour (Lubatkin, Schulze, Ling \& Dino, 2005) and routines, and consequently they tend to respond relatively slowly to environmental changes.

\subsection{Applying organisational ecology to family business research}

Given the potential difficulty of the family business in adapting, environments are believed to select the fittest family businesses to survive. Organisational ecology proposes that different characteristics of the environment affect the survival or mortality of a certain population of firms. This section contains suggestions and ideas on how organisational ecology can inform family business research when investigating the survival of family businesses.

Population density dynamics suggest that business survival should increase with the density of similar organisations. An increased density of family businesses in a certain industry lead to two different factors, higher social networks and legitimacy (cf. Bird \& Wennberg, 2014), which in turn are beneficial for the survival of family businesses. If the density of similar firms increases, so does the emergence of social network opportunities among such firms (Boone (Boone, Wezel \& van Witteloostuijn, 2013). This relationship is particularly evident in the context of family businesses, where at least two forms of social capital coexist: the family’s and the business' (Arregle et al., 2007; Sorenson \& Bierman, 2009). Due to its dependence on social networks, a family business may be more prone to survive in an industry characterised by a higher number of social network 
opportunities. ${ }^{4}$ Second, the presence of similar pre-existing forms of business in an industry will also enhance the legitimacy of these types of firms (Singh \& Lumsden, 1990). Legitimacy, in turn, facilitates resource acquisition, employee recruitment, and relationship building with suppliers and stakeholders (Audia, Freeman \& Reynolds, 2006), which are all be considered to be drivers of survival. The legitimisation of family businesses is, however, often hampered. Indeed, family businesses are often considered to be driven by parochial behaviour and perhaps self-serving family concerns (Le BretonMiller \& Miller, 2009) rather than by strictly business related goals. Family businesses, therefore, may be perceived as being less specialised than non-family businesses (Dyer, 1989), which may a problem for family business when it comes, for instance, to interactions with other industry shareholders. However, this perception is overcome in industries characterised by a high density of pre-existing family businesses, which in turn leads to the legitimation of these organisational forms (Singh \& Lumsden, 1990). This legitimation paves the way for the survival of other family businesses.

The organisational ecology model proposes that organisations are directly selected by environments (Hannan \& Freeman, 1977). The environment thus selects the fittest populations of organisations to survive in that environment via competition for resources between the inhabiting forms of organisation. The success of firm initiation and survival thus depend on the specific resource niche in which the firm is founded or operates. Many industries consist of multiple potential resource niches, and whereas some of these niches provide a fertile ground for some firms, others can be difficult to survive in (Carroll \& Khessina, 2005). I contend that family businesses are more likely to be selected by certain

\footnotetext{
${ }^{4}$ Gedajlovic \& Carney's (2010) proposition 1b (family firms are the predominant form of enterprise in industrial and institutional contexts where bonding forms of social capital are highly valued) and 2b (family firms are the predominant form of enterprise in industrial and institutional contexts where bridging forms of social capital are widely valued) (p. 1153) reinforce this view.
} 
industries and selected out by others, depending on the fit between the resources possessed by the family business and that needed to operate in the industry. For instance, family businesses may struggle to survive in industries characterised by highly skilled individuals because family businesses sometimes find it hard to gather such resources due to altruistic behaviour (see Schulze, Lubatkin \& Dino, 2003). Altruism can often make family businesses "less willing to offer certain (and as many) promotional opportunities to non-family agents, because selection criteria are generally based on family status, rather than on the agent's [...] skills” (Lubatkin et al., 2005, p. 320). Existing research proposes that family businesses are commonly "lean and mean" in their hiring and layoff practices with respect to skilled and professional human resources (Miller \& Le BretonMiller, 2005). Moreover, family businesses are believed to be less formalised in regard to human resource policies (De Kok, Uhlaner \& Thurik, 2006). Indeed, they place more emphasis on informal training and assign more importance to mentoring relationships (Fiegener, Brown, Prince \& File, 1996). Family managers are also believed to often bring an ownership mentality to human resource decisions and may view compensation, training, and benefits as expenses rather than investments (Gedajlovic \& Carney, 2010). The human resource practices described above are also consistent with a socioemotional wealth preservation motive in family businesses (Gomez-Mejia, Cruz, Berrone \& De Castro, 2011). Informal recruitment practices are more likely to focus on a small pool of candidates who share the family's values and culture and represent the ideal employee based on the unstated selection criterion of how the prospective employee will fit in with the family’s expectations (Cruz, Gómez-Mejia \& Becerra, 2010). Using social networks in the recruitment process reduces information asymmetries and ensures a better fit between the person and the organisational values (which are a reflection of family values). 
Therefore, due to these shortcomings in gathering important resources to compete in certain environments (i.e., recruitment of specialised workers), family businesses may experience higher mortality as the level of skilled labour required in a certain industry increases.

In other industries, however, the creation and transfer of tacit knowledge is often considered to be a resource on which a firm can build its competitive advantage (Foray \& Lundvall, 1998; Pathirage, Amaratunga \& Haigh, 2007). Family businesses have advantages in preserving and sustaining general tacit knowledge as it is best transferred in a learning-by-doing manner (Lane \& Lubatkin, 1998). In this respect, family businesses have been shown to be excellent mechanisms for preserving and transferring tacit knowledge between family members and from one generation to another (CabreraSuárez, De Saá-Pérez \& García-Almeida, 2001). On this point, research on family business succession indicates that they utilise a variety of formal and informal mechanisms to transfer tacit knowledge between generations (Steier, 2001). Relatedly, Sirmon and Hitt (2003) note that the early involvement of children in a family business can produce deep levels of tacit knowledge, and Miller and Le Breton-Miller (2006) suggest that a stewardship orientation in family managers inclines them to invest in the preservation of tacit knowledge through the development of a strong corporate culture and executive apprenticeship programs. As a consequence, as family businesses show an advantage in regard to preserving and sustaining tacit knowledge, they should show lower mortality rates when higher levels of tacit knowledge are embedded in an industry. 


\subsection{Opportunities for future research}

While the previous section provided some attempts to use density and fitness arguments to explore the relationship between characteristics of the industry and the survival of family businesses, many research opportunities exist to link organisational ecology to the survival of family businesses. One example can be given by concepts, such as the liability of newness and conditions at founding. Future research could focus on whether family businesses experience a liability of newness each time a succession process takes place because new members need to learn their new roles and positions in the firm; studies could then examine how this might impact the survival of the firm. Moreover, future research should also focus on the effect of the conditions at founding on the survival of new family firms. What founding conditions affect the survival of new family firms? Do such conditions differ from new non-family firms? How long might the impact of such conditions on new family business survival last? Overall research on new family businesses is lacking, with only a few studies (e.g., Bird \& Wennberg, 2014).

Another interesting theoretical aspect that arises from applying an organisational ecology perspective to family business studies is the level of analysis. Unlike existing studies in organisational ecology, a new level of analysis arises when focusing on family businesses: the family. This new level of analysis may be particularly interesting when theorising and operationalising family business mortality. Indeed, in family businesses, there exists a substantial difference between survival and longevity, the former referring to the persistence of control by the same family over time, while the latter refers to the age of the enterprise, independent of its ownership structure (Colli, 2011). Such concepts are instead used interchangeably in entrepreneurship research. This peculiarity of family businesses opens many interesting avenues for future research. For instance, future 
studies could explore whether structural inertia in (business) families is eventually transmitted to or inherited by the family business. Another interesting avenue for future research in family business is to explore whether not only business but also (business) families can be selected by the environments in which they operate and how this may affect the survival of the business. In this last example, the different conceptualisation and operationalisation between survival and longevity in family business provided by Colli (2011) becomes extremely relevant.

\section{Conclusion}

This study proposes an ecological perspective to the study of family business. It suggests some ideas on how organisational ecology's logic can be applied to investigate the effect of some environmental factors on the survival of family businesses. This study offers three primary contributions. First, it contributes to research in family business by adopting organisational ecology theory to study the survival of family businesses. While much of the previous research focused on the individual or organisational determinants of family business survival, this paper proposes that organisational ecology can be adopted to study the effect of certain environmental characteristics on the survival of family businesses as a distinct form of organisation. Second, this paper contributes to research in both entrepreneurship and family business by theorising that the systematic differences between family and non-family businesses primarily suggested by micro-oriented studies may also manifest themselves at the environmental level. This study finally contributes to research in organisational ecology by applying some core concepts of this perspective in a novel empirical context, i.e., the family business. Although family businesses are known to be driven by different dynamics than non-family businesses (Nordqvist \& Melin, 2010), organisational ecology appears to be a valid perspective to elucidate the 
survival of family versus non-family businesses depending on distinctive environmental characteristics. 


\section{References}

Aldrich, H. and Auster, E. R. (1986), 'Even Dwarfs Started Small: Liabilities ofAge and Size and Their Strategic Implications', Research in organizational behavior, 8 (1986), 165-186.

Aldrich, H. E. and Pfeffer, J. (1976), 'Environments of organizations', Annual review of sociology, 79-105.

Aldrich, H. E. and Cliff, J. E. (2003), 'The pervasive effects of family on entrepreneurship: Toward a family embeddedness perspective', Journal of Business Venturing, 18 (5), 573-596.

Amburgey, T. L. and Rao, H. (1996), 'Organizational ecology: Past, present, and future directions', Academy of Management Journal, 39 (5), 1265-1286.

Arregle, J. L., Hitt, M. A., Sirmon, D. G. and Very, P. (2007), 'The Development of Organizational Social Capital: Attributes of Family Firms*', Journal of management studies, 44 (1), 73-95.

Astley, W. G. and Van de Ven, A. H. (1983), 'Central perspectives and debates in organization theory', Administrative science quarterly, 245-273.

Audia, P. G., Freeman, J. H. and Reynolds, P. D. (2006), 'Organizational foundings in community context: Instruments manufacturers and their interrelationship with other organizations', Administrative science quarterly, 51 (3), 381-419.

Barnett, W. P. and Amburgey, T. L. (1989), 'Do larger organizations generate stronger competition?', in Organizational Evolution: New Directions, edited by J. V. Singh. Newbury Park, CA: Sage Publications. 
Baum, J. A. and Mezias, S. J. (1992), 'Localized competition and organizational failure in the Manhattan hotel industry, 1898-1990', Administrative science quarterly, 580-604.

Baum, J. A. C. (1996), 'Organizational Ecology', in Clegg, S. R., Hardy, C., Lawrence, T., \& Nord, W. R. (eds), The Sage handbook of organization studies, London: Sage, pp. 77-114

Bird, M. and Wennberg, K. (2014), 'Regional influences on the prevalence of family versus non-family start-ups', Journal of Business Venturing, 29 (3), 421-436.

Boone, C., Wezel, F. C. and van Witteloostuijn, A. (2013), 'Joining the pack or going solo? A dynamic theory of new firm positioning', Journal of Business Venturing, 28 (4), 511-527.

Cabrera-Suárez, K., De Saá-Pérez, P. and García-Almeida, D. (2001), 'The succession process from a resource-and knowledge-based view of the family firm', Family business review, 14 (1), 37-46.

Carcano, L., Corbetta, G. and Minichilli, A. (2011), 'Why luxury firms are often family firms? Family identity, symbolic capital and value creation in luxury-related industries', Universia Business Review, (32), 40-52.

Carney, M. (2005), 'Corporate Governance and Competitive Advantage in FamilyControlled Firms', Entrepreneurship Theory and Practice, 29 (3), 249-265.

Carroll, G. R. (1985), 'Concentration and specialization: Dynamics of niche width in populations of organizations', American journal of sociology, 1262-1283.

Carroll, G. R. and Delacroix, J. (1982), 'Organizational mortality in the newspaper industries of Argentina and Ireland: An ecological approach', Administrative science quarterly, 169-198. 
Carroll, G. R. and Hannan, M. T. (1989), 'Density dependence in the evolution of populations of newspaper organizations', American Sociological Review, 524541.

Carroll, G. R. and Khessina, O. M. (2005), 'The ecology of entrepreneurship', in :S.A. Alvarez, R. Agarwal, O. Sorenson (eds), Handbook of Entrepreneurship Research, Springer, pp. 167-200

Colli, A. (2011), 'Contextualizing performances of family firms: The perspective of business history', Family business review, 0894486511426872.

Cruz, C. C., Gómez-Mejia, L. R. and Becerra, M. (2010), 'Perceptions of benevolence and the design of agency contracts: CEO-TMT relationships in family firms', Academy of Management Journal, 53 (1), 69-89.

Davis, P., \& Stern, D. (1988). Adaptation, survival, and growth of the family business: An integrated systems perspective. Family Business Review, 1(1), 69-84.

De Kok, J. M., Uhlaner, L. M. and Thurik, A. R. (2006), 'Professional HRM Practices in Family Owned-Managed Enterprises', Journal of Small Business Management, 44 (3), 441-460.

Dyer, W. G. (1989), 'Integrating professional management into a family owned business', Family business review, 2 (3), 221-235.

Fiegener, M. K., Brown, B. M., Prince, R. A. and File, K. M. (1996), 'Passing on strategic vision: Favored modes of successor preparation by CEOs of family and nonfamily firms', Journal of Small Business Management, 34 (3), 15.

Foray, D. and Lundvall, B. (1998), 'The knowledge-based economy: from the economics of knowledge to the learning economy', The economic impact of knowledge, 115121. 
Freeman, J. and Hannan, M. T. (1983), 'Niche width and the dynamics of organizational populations', American journal of sociology, 1116-1145.

Freeman, J., Carroll, G. R. and Hannan, M. T. (1983), 'The liability of newness: Age dependence in organizational death rates', American Sociological Review, 692710.

Fritsch, M. and Falck, O. (2007), 'New business formation by industry over space and time: a multidimensional analysis', Regional Studies, 41 (2), 157-172.

Gedajlovic, E. and Carney, M. (2010), 'Markets, hierarchies, and families: Toward a transaction cost theory of the family firm', Entrepreneurship Theory and Practice, 34 (6), 1145-1172.

Gomez-Mejia, L. R., Larraza-Kintana, M. and Makri, M. (2003), 'The determinants of executive compensation in family-controlled public corporations', Academy of Management Journal, 46 (2), 226-237.

Gomez-Mejia, L. R., Cruz, C., Berrone, P. and De Castro, J. (2011), 'The bind that ties: Socioemotional wealth preservation in family firms', The academy of management annals, 5 (1), 653-707.

Gómez-Mejía, L. R., Haynes, K. T., Núñez-Nickel, M., Jacobson, K. J. and MoyanoFuentes, J. (2007), 'Socioemotional wealth and business risks in family-controlled firms: Evidence from Spanish olive oil mills', Administrative science quarterly, 52 (1), 106-137.

Habbershon, T. G. and Williams, M. L. (1999), 'A resource-based framework for assessing the strategic advantages of family firms', Family business review, 12 (1), 1-25. 
Hannan, M. T. (1986), A model of competitive and institutional processes in organizational ecology, Department of Sociology, Cornell University.

Hannan, M. T. and Freeman, J. (1977), 'The population ecology of organizations', American journal of sociology, 929-964.

Hannan, M. T. and Freeman, J. (1984), 'Structural inertia and organizational change', American Sociological Review, 149-164.

Lane, P. J. and Lubatkin, M. (1998), 'Relative absorptive capacity and interorganizational learning', Strategic management journal, 19 (5), 461-477.

Le Breton-Miller, I. and Miller, D. (2009), 'Agency vs. stewardship in public family firms: A social embeddedness reconciliation', Entrepreneurship Theory and Practice, 33 (6), 1169-1191.

Levins, R. (1962), 'Theory of fitness in a heterogeneous environment. I. The fitness set and adaptive function', American Naturalist, 361-373.

Lubatkin, M. H., Schulze, W. S., Ling, Y. and Dino, R. N. (2005), 'The effects of parental altruism on the governance of family-managed firms', Journal of organizational behavior, 26 (3), 313-330.

Lumpkin, G., Brigham, K. H. and Moss, T. W. (2010), 'Long-term orientation: Implications for the entrepreneurial orientation and performance of family businesses', Entrepreneurship and Regional Development, 22 (3-4), 241-264.

Miller, D. and Le Breton-Miller, I. (2005), Managing for the long run: Lessons in competitive advantage from great family businesses, Harvard Business Press. Harvard, MA

Miller, D. and Le Breton-Miller, I. (2006), 'Family governance and firm performance: Agency, stewardship, and capabilities', Family business review, 19 (1), 73-87. 
Miller, D., Le Breton-Miller, I. and Lester, R. H. (2011), 'Family and lone founder ownership and strategic behaviour: Social context, identity, and institutional logics', Journal of management studies, 48 (1), 1-25.

Nordqvist, M. and Melin, L. (2010), 'Entrepreneurial families and family firms', Entrepreneurship and Regional Development, 22 (3-4), 211-239.

Pathirage, C. P., Amaratunga, D. G. and Haigh, R. P. (2007), 'Tacit knowledge and organisational performance: construction industry perspective', Journal of knowledge management, 11 (1), 115-126.

Pennings, J. M. (1982), 'Organizational birth frequencies: An empirical investigation', Administrative science quarterly, 120-144.

Romanelli, E. (1989), 'Environments and strategies of organization start-up: Effects on early survival', Administrative science quarterly, 369-387.

Schulze, W. S., Lubatkin, M. H. and Dino, R. N. (2003), 'Toward a theory of agency and altruism in family firms', Journal of Business Venturing, 18 (4), 473-490.

Sharma, P. (2004), 'An overview of the field of family business studies: Current status and directions for the future', Family business review, 17 (1), 1-36.

Singh, J. V. and Lumsden, C. J. (1990), 'Theory and research in organizational ecology', Annual review of sociology, 161-195.

Sirmon, D. G. and Hitt, M. A. (2003), 'Managing resources: Linking unique resources, management, and wealth creation in family firms', Entrepreneurship Theory and Practice, 27 (4), 339-358.

Sorenson, R. L. and Bierman, L. (2009), 'Family Capital, Family Business, and Free Enterprise', Family business review, 22 (3), 193-195. 
Steier, L. (2001), 'Next-generation entrepreneurs and succession: An exploratory study of modes and means of managing social capital', Family business review, 14 (3), 259-276.

Stinchcombe, A. L. (1965). 'Social structure and organizations'. In J. G. March (Ed.), Handbook of organizations. Chicago: Rand McNally, 142-193.

Swaminathan, A. (1996), 'Environmental conditions at founding and organizational mortality: A trial-by-fire model', Academy of Management Journal, 39 (5), 13501377.

The Economist (2009) European family firms in the recession Dynasty and durability Data accessed : November 2013 . Url: www.economist.com/node/14517406

Ward, J. L. (1988), 'The special role of strategic planning for family businesses', Family business review, 1 (2), 105-117.

Westhead, P. and Cowling, M. (1998), 'Family firm research: The need for a methodological rethink', Entrepreneurship Theory and Practice, 23 31-56.

Wholey, D. R. and Brittain, J. W. (1986), 'Organizational ecology: Findings and implications', Academy of Management Review, 11 (3), 513-533.

Wiklund, J., Nordqvist, M., Hellerstedt, K. and Bird, M. (2013), 'Internal versus external ownership transition in family firms: An embeddedness perspective', Entrepreneurship Theory and Practice, 37 (6), 1319-1340.

Villalonga, B. and Amit, R. (2006), 'How do family ownership, control and management affect firm value?', Journal of financial Economics, 80 (2), 385-417.

Wilson, N., Wright, M. and Scholes, L. (2013), 'Family business survival and the role of boards', Entrepreneurship Theory and Practice, 37 (6), 1369-1389. 
Wortman, M. S. (1994), 'Theoretical foundations for family-owned business: A conceptual and research-based paradigm', Family business review, 7 (1), 3-27.

Zahra, S. A., Hayton, J. C. and Salvato, C. (2004), 'Entrepreneurship in family vs. NonFamily firms: A Resource-Based analysis of the effect of organizational culture', Entrepreneurship Theory and Practice, 28 (4), 363-381. 